\title{
USING BOARD GAMES TO ENGAGE NON- INTERESTED STUDENTS IN ACCOUNTING CLASSES
}

\author{
Kelly Damron, Grand Canyon University
}

\begin{abstract}
A board game is used in financial accounting courses as a means to engage students actively in their own learning. Since many students are intimidated by accounting or find the topic uninteresting, the use of games, especially a board game, encourages them to engage actively. After playing the board game, the students in the classroom appreciate a better connection between the accounting topics they learned and how to use accounting in their professional or personal lives. This activity requires the faculty member to run an organized classroom and ensure students are completing the activity as directed.
\end{abstract}

Keywords: accounting classroom, active learning, student engagement

\section{INNOVATIVE AND PRACTICAL TEACHING PRACTICE}

Active learning is classroom instruction that engages students in their own learning (Burney, Zascavage, \& Matherly, 2017). Burney et al. (2017) indicated undergraduate students had increased satisfaction and developed a deeper level of understanding from authentic active learning strategies. Dai (2019) suggested students lack motivation to learn accounting because teaching effectiveness is poor. Students only gain passive knowledge because they are not engaged in active learning strategies (Dai, 2019). An innovative and active teaching practice used in the course, Financial Accounting, is tweaking the rules of Monopoly to make it relevant to accounting. In the modified version of Monopoly, students practice preparing journal entries based on the transaction occurring in the game. For example, if a student lands on a railroad property, they have the option to purchase the railroad and will record the corresponding journal entry. To wrap-up the exercise, the students discuss how the journal entries they created as they moved from space to space resemble real-world transactions.

\section{Obstacle}

Every student pursuing a bachelor's degree in business must complete at least one accounting course, and many of these students are intimidated by accounting or do not see the relevance to their business degree. Ou (2019) indicated students' interest in learning is dependent on various factors, such as their individual personalities, interest in the subject matter, and motivation. Students who are interested in the course concepts tend to complete the objectives easily and expand their knowledge (Ou, 2019). When students are not interested in the concepts, they may need continuous encouragement by faculty to make the effort to learn (Ou, 2019). As faculty, it is our responsibility to motivate students and help them overcome learning difficulties (Kirpalani, 2017). A study conducted by Burney et al. (2017) found students were motivated to work harder in the class when they utilized active learning strategies. Students also indicated the active learning activities helped make difficult concepts easier to understand and changed their attitudes toward studying (Burney et al., 2017).

There are several obstacles to try to overcome when teaching students who lack an interest in the subject matter, but the main concern was instilling the usefulness of accounting to students' future careers, as well as their personal lives. Exercises from the textbook are practical and help students learn the basic concepts associated with accounting transactions. However, textbook examples can be boring, and students do not often see the connection between the text in the book 
and real-world transactions. Faculty must help students understand how a class like financial accounting applies to their degree, future careers, and their personal lives (Kipalani, 2017). A game often engages even the most uninterested student. Before implementing Monopoly in the classroom, other activities, such as Jeopardy, crossword puzzles, and word searches were used. Students seemed to enjoy the non-traditional activities, and these activities engaged students in a different way than traditional lectures or textbook examples did. Pennington (2015) indicated students stated the hands-on activities encouraged them to be more engaged. Students stated the activities Pennington (2015) used to engage students were enjoyable and informative. Burney et al. (2017) noted students believed active learning activities were worthwhile, useful, and helped them feel more comfortable participating during class meetings.

\section{Solution}

To overcome students' dislike or lack of relevance toward a topic, it needs to be practical and fun. For students, playing a board game does not seem like learning. Instead, students see it as a social activity as well as a break from the monotony of traditional in-class discussion or exercise. Students learn while they are playing in a more meaningful way than with professors working through exercises on the board. In a study conducted by Pennington (2015), it was noted that students considered the activities used in class as valuable, and students felt they were able to make a better connection to theory and practice. In this case, they also learned from each other because they helped one another determine what the proper accounting journal entry should be for a particular transaction. The feedback from students was that the game seemed more like real-world transactions than activities out of the book.

\section{Implementation}

Using Monopoly to practice journal entries works best in class sizes of 40 or less students. Using five game boards, students are placed in to groups of four. They are encouraged to start with $\$ 1,000$ and to use the extra cards, such as "Chance," as they would in a normal game. They record the first journal entry, which is the receipt of cash and increase in owners' equity. Students may roll the dice to see who goes first or just start playing. As the students play the game, the faculty member walks around the room to answer any questions and ensure students are recording the journal entries properly based on the transaction associated with their roll. Since there are only 20 students playing the game at a time, the class is split in half so that half of the students play and the other half work on an exercise from the textbook.

Approximately 30 minutes is allocated to the first group playing the game. After 30 minutes, the teams rotate activities so that the students completing the textbook exercise are provided with a game board and start playing. The students who were previously playing Monopoly are encouraged to create a trial balance or income statement and balance sheet from their game generated journal entries. Once they complete that activity, they too work on the comprehensive textbook problem. Since class periods are 70 minutes, students are encouraged to put away the board game when there are about 10 minutes remaining. The instructor then leads the class in a discussion about what they learned while playing the game.

\section{Lessons Learned}

When using an activity, such as Monopoly, time management is extremely important so that all students get an equal chance to play and practice. While 30 minutes is not a long time for students to play the game, it does give them a chance to round the board a few times and record a significant number of journal entries. Students often want to play the game longer, so it can be challenging ensuring the second group has enough play time if the first group is slow to quit playing the game. Using a game can be a distraction for some students who really do not want to participate in the activity as instructed. These students may try to convince their group just to play Monopoly the "regular" way instead of using the accounting approach. A group that is just having fun instead of following instructions may become a distraction for the entire class. The goal for faculty is to support student individual learning styles by offering a variety of activities, yet ensure students are challenged to think critically and improve students' knowledge of the subject matter (Kipalani, 2017). In a group setting, students may be more sensitive to constructive criticism associated with the correctness of their work, so it is recommended any feedback about how to properly 
prepare the journal entry based on the transaction should be directed to the entire group and not the single student.

\section{CONCLUSION}

The original goal for implementing the use of games, such as Monopoly, was to show students the relevance of the topic material and provide an element of fun. Since many students find accounting an intimidating topic, creating a fun learning environment allows them to engage with the concepts in a safe and enjoyable manner. Frequently the students enjoy the game so much they ask if they can play it again or for the entire class period. Unfortunately, there is a lot of content to cover in an introductory accounting course, so the time allocated for non-traditional activities is limited and has to be managed so as not to reduce the time allotted to cover topics student need to know for assignments or exams.

Usually even the most unengaged student will participate and enjoy playing Monopoly accounting style, similar to the findings by Burney et al. (2017) and Pennington (2015). After playing the game, which is usually about the fifth or sixth week of class, there is improved interaction between students when working on group activities. The element of fun from Monopoly can sometimes help students create friendships or study groups. Another noticeable change is that students seem to be less bored with the topic, or at least start to see accounting as more relevant, after playing the game as discussed by Pennington (2015). In some classes, there is a dramatic increase in participation by students who had not participated the first six weeks. In other cases, there is no change in participation, but a noticeable increase in students working together when the professor requires them to work in groups. Burney et al. (2017) stated students had an improved opinion about accounting and found accounting more interesting after completing the active learning exercises. Dai (2019) suggested students learn best when faculty utilize active learning strategies. Accounting faculty are especially burdened with creating a classroom environment where students can relate to the topic matter and are engaged in their own learning (Dai, 2019; Kirpalani, 2017). Playing a board game in an accounting classroom requires skill by the faculty to appropriately manage the classroom, but must also be innovative enough to encourage change in student dislike or behavior toward the topic. 


\section{References}

Burney, L., Zascavage, V., \& Matherly, M. (2017). Advancing accounting research of teaching efficacy: Developing a scale to measure student attitudes toward active learning experiences. Leadership and Research in Education, 4(1), 55-76.

Dai, S. (2019). ARS interactive teaching mode for financial accounting course based on a Smart classroom. International Journal of Emerging Technologies in Learning, 14(3), 38-49. doi:10.3991/ijet_v14i03.10104

Kirpalani, N. (2017). Developing self-reflective practices to improve teaching effectiveness. Journal of Higher Education Theory \& Practice, 17(8), 73-80.

Ou, X. (2019). Differential classification method in different teaching models of accounting courses based on Naïve Bayesian classification algorithm. International Journal of Emerging Technologies in Learning, 14(8), 38-51. doi:10.3991/ijet_v14i08.10395

Pennington, S. E. (2015). Inquiry into teaching: Using reflective teaching to improve my practice. Networks, 17(1), 1-11. 